AL-MARSHAD: JURNAL ASTRONOMI ISLAM DAN ILMU-ILMU BERKAITAN

ISSN 2442-5729 (print) || ISSN 2598-2559 (online), http://jurnal.umsu.ac.id/index.php/almarshad DOI: https://doi.org/10.30596/jam.v4i1.1935

Published June 2018

\title{
Analisis Regresi Non Linier (Polinomial) Dalam Pembentukan Kriteria Visibilitas
}

\section{Hilal Di Indonesia}

\author{
Imas Musfiroh ${ }^{1 *}$ Hendri $^{2}$ \\ Institut Agama Islam Bukittinggi \\ ${ }^{1}$ Email: imasmusfiroh1990@gmail.com \\ 2Email: hendridatuak7@gmail.com
}

\begin{abstract}
Abstrak
Dalam penelitian ini menunjukkan bahwa koefisien determinasi terbesar diperoleh dari hubungan semidiameter toposentrik dengan fraksi iluminasi bernilai 0,945; disusul kemudian altitude toposentrik dengan lebar hilal bernilai 0,915; lebar hilal-elongasi bernilai 0,912; elongasi-altitude toposentrik bernilai 0,9066 dan nilai koefisien terendah diperoleh dari hubungan selisih azimut dengan altitude toposentrik dan elongasi berturut-berturut bernilai 0,352 dan 0,318. Berdasarkan nilai koefisien determinasi ini juga terlihat bahwa azimut tidak begitu signifikan mempengaruhi altitude toposentrik dan elongasi karena nilai koefisien yang rendah. Namun di sisi lain, lebar hilal, umur hilal elongasi dan ketinggian hilal saling memengaruhi satu sama lain dengan begitu signifikan karena nilai koefisien yang cukup besar mendekati. Kriteria terbaik dibentuk berdasarkan altitude toposentrik dan elongasi atau altitude toposentrik dengan lebar hilal toposentrik. Kriteria Altitude-Elongasi dengan persamaan $\boldsymbol{h} \geq 0,0445 \boldsymbol{A R C L ^ { 2 } - 0 , 6 0 6 5} \boldsymbol{A R C L}+4,0165^{\circ}$ memiliki titik balik minimum pada $6,815^{\circ}$ untuk elongasi dan $1,950^{\circ}$ untuk altitude. kriteria Altitude-Lebar Hilal dengan persamaan $\boldsymbol{h} \geq$ $0,9373 W^{3}-3,6892 W^{2}+11,596 W^{3}+1,4057^{\circ}$ memiliki titik belok pada 1,312 menit busur untuk lebar hilal dan $12,386^{\circ}$ untuk altitude.
\end{abstract}

\section{Artikel Info}

Received:

13 Februari 2018

Revised:

12 Maret 2018

Accepted:

20 Mei 2018

Keyword: visibilitas hilal, regresi polinomial.

\section{A. Pendahuluan}

Upaya memprediksi kenampakan

hilal (sabit Bulan yang terbentuk pascakonjungsi) telah dilakukan oleh para pengamat langit sejak era Babilonia hingga zaman modern.
Hingga saat ini dapat dijumpai beragam kriteria visibilitas atau kenampakan hilal, namun tidak ada kriteria yang berlaku universal untuk seluruh lintang 
geografis. ${ }^{1}$ Berdasarkan hal tersebut, untuk menyatukan kriteria-kriteria visibilitas Hilal yang ada saat ini di Indonesia dan juga di mancanegara, diperlukan basis ilmiah yang kuat. Basis ilmiah yang kuat menurut Moh. Ilyas dapat didekati dengan dua pendekatan, yang salah satunya adalah dilakukannya pengamatan Hilal secara berkesinambungan untuk selanjutnya dianalisis secara astronomis. ${ }^{2}$ Untuk melakukan hal tersebut maka penting untuk mengetahui kembali makna hilal yang sesungguhnya.

Dari sudut pandang pengamatan astronomi, pengertian Hilal tersebut dapat dikarakterisasi dengan lima elemen berikut, yaitu DAz, ArcV, ArcL, Age, dan Lag. Daz atau Delta Azimuth adalah selisih azimuth antara Hilal dan Matahari. ArcV yang disebut juga dengan Arc of Vision adalah selisih ketinggian antara Hilal dan Matahari. Jarak sudut antara Hilal dan Matahari dikenal dengan elongasi atau Arc of Light (ArcL). Secara skematis ketiganya

${ }^{1}$ Hoffman, R.E. Observing the New Moon. Mon. Not. R. Astron. Soc. 2003, 340: 1039 - 1051.

${ }^{2}$ Ilyas, M. A Modern Guide to Astronomical Calculations of Islamic Calendar, Times and Qibla. (Kuala Lumpur: Berita, 1984.) diilustrasikan pada Gambar 1 dan satuan ketiganya dinyatakan dalam besaran sudut. Adapun umur Hilal atau Age adalah waktu yang dihitung sejak terjadinya konjungsi hingga Matahari terbenam saat pengamatan Hilal muda dilakukan atau sejak terjadinya Matahari terbit hingga konjungsi. Untuk Hilal tua, Age dinyatakan dalam satuan jam. Lag sendiri adalah selisih antara waktu terbenam/terbit Hilal dan Matahari serta dinyatakan dalam satuan menit. Kelima elemen ini dinyatakan pada kondisi toposentrik, yaitu pengamat berada di permukaan Bumi. ${ }^{3}$ Adapun konjungsi dinyatakan pada kondisi geosentrik, yaitu pengamat diandaikan berada di pusat Bumi.

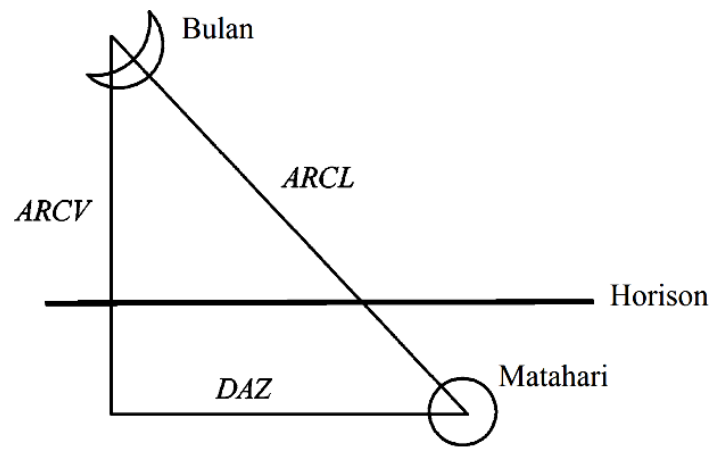

Gambar 1 Skema Posisi Hilal dan Matahari

${ }^{3}$ Odeh, M. Sh. 2004. New Criterion for Lunar Crescent Visibility. Experimental Astronomy. 18: 39-64. 
Fokus penelitian ini lebih kepada mencari hubungan antara parameter fisis dan empiris hilal dan mencari model persamaan menggunakan regresi non linier (polinomial). Analisis regresi polinomial dianggap sebagai model terbaik berdasarkan pertimbangan sebagai berikut: 1) untuk mencari nilai $\mathrm{R}$ (korelasi) yang besar. 2) untuk mencari nilai $\mathrm{R}^{2}$ yang besar dengan 3 ) standard eror yang kecil. Model ini dapat memprediksi kenampakan hilal yang di formulasikan ke dalam kriteria visibilitas hilal.

\section{B. Data dan Pembahasan}

Data yang penulis sajikan dalam penelitian ini diperoleh berdasarkan 88 kompilasi data rukyatul hilal Kemenag
(1962 - 2010) dan 68 kompilasi data rukyatul hilal positif dan BMKG (2008 - 2015), sehingga jumlah data menjadi 156. Namun dari 88 data dari Kemenag ini kemudian direduksi dengan kriteria imkanur rukyat MABIMS, sehingga diperoleh 68 data dan total keseluruhan data berjumlah 136.

Berikut ini data yang telah penulis sarikan. Data pertama hingga data ke-68 merupakan data dari Kemenag sedangkan data ke-69 hingga data ke136 merupakan data dari BMKG. Dalam tabel ini, nilai semidiameter (SD) dan paralaks (pi) Bulan diperoleh ketika jarak Bumi-Bulan 384400 km (rata-rata) dan dianggap sama untuk semua data.

Tabel 1 Kompilasi Data Rukyatul Hilal di Indonesia 1962-2015

\begin{tabular}{|c|c|c|c|c|c|c|c|c|c|c|c|}
\hline No. & Miladi & Hijri & $\begin{array}{c}\text { Lat. } \\
\left({ }^{\circ}\right)\end{array}$ & $\begin{array}{c}\text { Lon. } \\
\left({ }^{\circ}\right)\end{array}$ & $\begin{array}{c}\text { H } \\
\left({ }^{\circ}\right)\end{array}$ & $\begin{array}{c}\text { ARCL } \\
\left({ }^{\circ}\right)\end{array}$ & $\begin{array}{c}\text { DAZ } \\
\left({ }^{\circ}\right)\end{array}$ & $\begin{array}{c}\text { AGE } \\
(\text { jam })\end{array}$ & $\begin{array}{c}\text { FI } \\
(\%)\end{array}$ & $\begin{array}{c}\text { SD' } \\
(')\end{array}$ & $\begin{array}{c}\text { W' } \\
(')\end{array}$ \\
\hline I & II & III & \multicolumn{1}{|c|}{ IV } & \multicolumn{1}{|c|}{ V } & VI & VII & VIII & IX & X & XI & XII \\
\hline 1 & $05 / 02 / 1962$ & $01 / 09 / 1381$ & -7.03 & 106.56 & 4.61 & 2.36 & 5.18 & 11.14 & 0.04 & 16.57 & 0.01 \\
\hline 2 & $15 / 01 / 1964$ & $01 / 09 / 1383$ & -6.13 & 106.83 & 5.66 & 5.67 & 0.31 & 14.50 & 0.24 & 16.81 & 0.08 \\
\hline 3 & $15 / 01 / 1964$ & $01 / 09 / 1383$ & -6.18 & 106.82 & 5.69 & 5.70 & 0.32 & 14.88 & 0.25 & 16.82 & 0.08 \\
\hline 4 & $15 / 01 / 1964$ & $01 / 09 / 1383$ & -6.32 & 107 & 5.68 & 5.69 & 0.35 & 14.53 & 0.25 & 16.81 & 0.08 \\
\hline 5 & $12 / 12 / 1966$ & $01 / 09 / 1386$ & -0.16 & 106.92 & 2.89 & 4.18 & 3.02 & 7.74 & 0.13 & 16.18 & 0.04 \\
\hline 6 & $12 / 12 / 1966$ & $01 / 09 / 1386$ & -6.18 & 106.83 & 3.08 & 4.32 & 3.02 & 7.75 & 0.14 & 16.22 & 0.05 \\
\hline 7 & $12 / 12 / 1966$ & $01 / 09 / 1386$ & -6.18 & 106.63 & 2.95 & 4.24 & 3.04 & 7.84 & 0.14 & 16.20 & 0.04 \\
\hline 8 & $12 / 12 / 1966$ & $01 / 09 / 1386$ & -6.32 & 107 & 2.93 & 4.19 & 2.99 & 7.78 & 0.13 & 16.19 & 0.04 \\
\hline 9 & $20 / 12 / 1968$ & $01 / 09 / 1388$ & -6.09 & 106.88 & 8.91 & 9.73 & 3.91 & 16.72 & 0.72 & 17.54 & 0.25 \\
\hline 10 & $20 / 12 / 1968$ & $01 / 09 / 1388$ & -6.19 & 106.93 & 8.92 & 9.73 & 3.88 & 16.72 & 0.72 & 17.54 & 0.25 \\
\hline
\end{tabular}


AL-MARSHAD: JURNAL ASTRONOMI ISLAM DAN ILMU-ILMU BERKAITAN

ISSN 2442-5729 (print) || ISSN 2598-2559 (online), http://jurnal.umsu.ac.id/index.php/almarshad DOI: https://doi.org/10.30596/jam.v4i1.1935

Published June 2018

\begin{tabular}{|c|c|c|c|c|c|c|c|c|c|c|c|}
\hline 11 & $20 / 12 / 1968$ & 01/09/1388 & -7.03 & 106.56 & 9.09 & 9.82 & 3.71 & 16.80 & 0.73 & 17.58 & 0.26 \\
\hline 12 & $10 / 11 / 1968$ & $01 / 09 / 1389$ & -6.18 & 106.83 & 4.77 & 7.43 & 5.70 & 12.56 & 0.42 & 16.61 & 0.14 \\
\hline 13 & $10 / 11 / 1968$ & $01 / 09 / 1389$ & -6.23 & 106.83 & 4.60 & 7.31 & 5.68 & 12.58 & 0.41 & 16.57 & 0.13 \\
\hline 14 & $10 / 11 / 1968$ & $01 / 09 / 1389$ & -6.32 & 107 & 4.62 & 7.32 & 5.68 & 12.61 & 0.41 & 16.57 & 0.14 \\
\hline 15 & $10 / 11 / 1968$ & $01 / 09 / 1389$ & -6.09 & 106.88 & 4.57 & 5.61 & 7.24 & 12.57 & 0.24 & 16.56 & 0.08 \\
\hline 16 & $10 / 11 / 1968$ & $01 / 09 / 1389$ & -7.03 & 106.56 & 4.77 & 5.62 & 7.37 & 12.62 & 0.24 & 16.61 & 0.08 \\
\hline 17 & $06 / 11 / 1972$ & $01 / 10 / 1392$ & -6.09 & 106.88 & 2.08 & 5.10 & 5.51 & 9.39 & 0.20 & 16.00 & 0.06 \\
\hline 18 & $06 / 11 / 1972$ & $01 / 10 / 1392$ & -6.32 & 107 & 2.12 & 5.08 & 5.51 & 9.43 & 0.20 & 16.01 & 0.06 \\
\hline 19 & $06 / 09 / 1975$ & $01 / 09 / 1395$ & -6.13 & 106.83 & 5.86 & 6.92 & 9.07 & 15.53 & 0.36 & 16.85 & 0.12 \\
\hline 20 & $06 / 09 / 1975$ & $01 / 09 / 1395$ & -6.32 & 107 & 5.91 & 6.89 & 9.08 & 15.55 & 0.36 & 16.87 & 0.12 \\
\hline 21 & $06 / 09 / 1975$ & $01 / 09 / 1395$ & -6.27 & 106.48 & 5.93 & 6.90 & 9.10 & 15.56 & 0.36 & 16.87 & 0.12 \\
\hline 22 & $06 / 09 / 1975$ & $01 / 09 / 1395$ & -7.03 & 106.56 & 6.05 & 6.82 & 9.12 & 15.55 & 0.35 & 16.90 & 0.12 \\
\hline 23 & $15 / 08 / 1977$ & $01 / 09 / 1397$ & -6.16 & 106.94 & 4.08 & 5.14 & 6.56 & 13.34 & 0.20 & 16.45 & 0.07 \\
\hline 24 & $15 / 08 / 1977$ & $01 / 09 / 1397$ & -7.03 & 106.56 & 4.28 & 5.06 & 6.63 & 13.37 & 0.19 & 16.50 & 0.06 \\
\hline 25 & $04 / 08 / 1978$ & $01 / 09 / 1398$ & -6.21 & 106.46 & 2.51 & 4.11 & 4.82 & 9.90 & 0.13 & 16.10 & 0.04 \\
\hline 26 & $04 / 08 / 1978$ & $01 / 09 / 1398$ & -6.16 & 106.94 & 2.44 & 4.12 & 4.79 & 9.85 & 0.13 & 16.08 & 0.04 \\
\hline 27 & $04 / 08 / 1978$ & $01 / 09 / 1398$ & -7.03 & 106.56 & 2.65 & 4.06 & 4.85 & 9.88 & 0.13 & 16.13 & 0.04 \\
\hline 28 & $04 / 08 / 1978$ & $01 / 09 / 1398$ & -6.52 & 109.09 & 2.43 & 4.07 & 4.74 & 9.73 & 0.13 & 16.08 & 0.04 \\
\hline 29 & $24 / 07 / 1979$ & $01 / 09 / 1399$ & -6.16 & 106.94 & 2.49 & 3.33 & 4.16 & 9.17 & 0.08 & 16.09 & 0.03 \\
\hline 30 & $24 / 07 / 1979$ & $01 / 09 / 1399$ & -7.03 & 106.56 & 2.66 & 3.27 & 4.22 & 9.19 & 0.08 & 16.13 & 0.03 \\
\hline 31 & $11 / 08 / 1980$ & $01 / 10 / 1400$ & -8.75 & 116.04 & 5.62 & 0.59 & 5.65 & 15.09 & 0.00 & 16.80 & 0.00 \\
\hline 32 & $11 / 08 / 1980$ & $01 / 10 / 1400$ & -7.03 & 106.56 & 6.01 & 0.87 & 6.08 & 15.74 & 0.01 & 16.89 & 0.00 \\
\hline 33 & $11 / 08 / 1980$ & $01 / 10 / 1400$ & -6.27 & 106.49 & 5.93 & 0.95 & 6.01 & 15.76 & 0.01 & 16.87 & 0.00 \\
\hline 34 & $11 / 08 / 1980$ & $01 / 10 / 1400$ & -6.16 & 106.94 & 5.86 & 0.98 & 5.94 & 15.71 & 0.01 & 16.85 & 0.00 \\
\hline 35 & $02 / 07 / 1981$ & $01 / 09 / 1401$ & -7.03 & 106.56 & 7.41 & 0.70 & 7.45 & 15.74 & 0.00 & 17.20 & 0.00 \\
\hline 36 & $02 / 07 / 1981$ & $01 / 09 / 1401$ & -7.73 & 114.02 & 6.94 & 0.55 & 6.96 & 15.23 & 0.00 & 17.10 & 0.00 \\
\hline 37 & $21 / 07 / 1982$ & $01 / 10 / 1402$ & 0.76 & 127.34 & 7.15 & 0.09 & 7.15 & 14.75 & 0.00 & 17.15 & 0.00 \\
\hline 38 & $21 / 07 / 1982$ & $01 / 10 / 1402$ & -8.75 & 116.4 & 7.27 & 1.79 & 7.49 & 15.26 & 0.02 & 17.17 & 0.01 \\
\hline 39 & $21 / 07 / 1982$ & $01 / 10 / 1402$ & -7.03 & 106.56 & 7.92 & 1.44 & 8.05 & 15.93 & 0.02 & 17.32 & 0.01 \\
\hline 40 & $16 / 05 / 1988$ & $01 / 10 / 1408$ & -6.16 & 106.94 & 3.01 & 6.76 & 7.40 & 12.50 & 0.35 & 16.21 & 0.11 \\
\hline 41 & $16 / 05 / 1988$ & $01 / 10 / 1408$ & -6.22 & 106.92 & 3.04 & 6.77 & 7.42 & 12.50 & 0.35 & 16.22 & 0.11 \\
\hline 42 & $27 / 03 / 1990$ & $01 / 09 / 1410$ & -7.03 & 106.56 & 4.00 & 7.48 & 8.48 & 15.19 & 0.43 & 16.43 & 0.14 \\
\hline 43 & $27 / 03 / 1990$ & $01 / 09 / 1410$ & -6.16 & 106.94 & 3.97 & 8.20 & 9.11 & 15.14 & 0.51 & 16.43 & 0.17 \\
\hline 44 & $15 / 04 / 1991$ & $01 / 10 / 1411$ & -6.16 & 106.94 & 3.70 & 8.30 & 9.09 & 15.18 & 0.52 & 16.37 & 0.17 \\
\hline 45 & $15 / 04 / 1991$ & $01 / 10 / 1411$ & -6.22 & 112.62 & 3.73 & 8.31 & 9.11 & 15.18 & 0.52 & 16.37 & 0.17 \\
\hline 46 & $15 / 04 / 1991$ & $01 / 10 / 1411$ & -6.15 & 106.8 & 3.75 & 8.31 & 9.12 & 15.20 & 0.52 & 16.38 & 0.17 \\
\hline
\end{tabular}

Copyright (C 2018. Al-Marshad: Jurnal Astronomi Islam dan Ilmu-Ilmu Berkaitan. This is an open acces article under the CC-BY-SA lisence (https://creativecommons.org/licenses/by-sa/4.0/). 
AL-MARSHAD: JURNAL ASTRONOMI ISLAM DAN ILMU-ILMU BERKAITAN

ISSN 2442-5729 (print) || ISSN 2598-2559 (online), http://jurnal.umsu.ac.id/index.php/almarshad DOI: https://doi.org/10.30596/jam.v4i1.1935

Published June 2018

\begin{tabular}{|c|c|c|c|c|c|c|c|c|c|c|c|}
\hline 47 & $15 / 04 / 1991$ & $01 / 10 / 1411$ & -7.03 & 106.56 & 3.73 & 8.39 & 9.18 & 15.23 & 0.54 & 16.37 & 0.18 \\
\hline 48 & $31 / 01 / 1995$ & $01 / 09 / 1415$ & 1.29 & 124.52 & 3.00 & 6.35 & 7.02 & 11.13 & 0.31 & 16.21 & 0.10 \\
\hline 49 & $31 / 01 / 1995$ & $01 / 09 / 1415$ & -7.03 & 106.56 & 2.86 & 7.29 & 7.83 & 12.51 & 0.40 & 16.17 & 0.13 \\
\hline 50 & $19 / 02 / 1996$ & $01 / 10 / 1416$ & -7.03 & 106.56 & 2.95 & 6.14 & 6.81 & 11.75 & 0.29 & 16.20 & 0.09 \\
\hline 51 & $19 / 02 / 1996$ & $01 / 10 / 1416$ & -6.16 & 106.94 & 2.89 & 6.07 & 6.72 & 11.70 & 0.28 & 16.18 & 0.09 \\
\hline 52 & $19 / 02 / 1996$ & $01 / 10 / 1416$ & -7.17 & 112.62 & 2.84 & 6.07 & 6.70 & 11.35 & 0.28 & 16.17 & 0.09 \\
\hline 53 & $02 / 11 / 2005$ & $01 / 10 / 1426$ & -7.17 & 112.62 & 2.76 & 3.50 & 4.46 & 8.96 & 0.09 & 16.15 & 0.03 \\
\hline 54 & $02 / 11 / 2005$ & $01 / 10 / 1426$ & -6.16 & 106.94 & 2.63 & 3.62 & 4.47 & 9.31 & 0.10 & 16.12 & 0.03 \\
\hline 55 & $31 / 12 / 2005$ & $01 / 12 / 1426$ & -6.16 & 106.94 & 3.89 & 3.99 & 5.57 & 7.92 & 0.12 & 16.41 & 0.04 \\
\hline 56 & $31 / 12 / 2005$ & $01 / 12 / 1426$ & -7.59 & 112.4 & 3.90 & 3.86 & 5.49 & 7.62 & 0.11 & 16.41 & 0.04 \\
\hline 57 & $12 / 09 / 2007$ & $01 / 09 / 1428$ & -8.07 & 110.32 & 7.74 & 4.94 & 9.18 & 21.86 & 0.19 & 17.28 & 0.06 \\
\hline 58 & $12 / 10 / 2007$ & $01 / 10 / 1428$ & -7.17 & 112.62 & 10.29 & 7.63 & 12.81 & 29.35 & 0.44 & 17.85 & 0.16 \\
\hline 59 & $31 / 08 / 2008$ & $01 / 09 / 1429$ & -7.17 & 112.62 & 5.27 & 4.29 & 6.80 & 14.49 & 0.14 & 16.72 & 0.05 \\
\hline 60 & $31 / 08 / 2008$ & $01 / 09 / 1429$ & -8.07 & 110.32 & 5.09 & 4.22 & 6.61 & 14.65 & 0.14 & 16.68 & 0.05 \\
\hline 61 & $31 / 08 / 2008$ & $01 / 09 / 1429$ & -4.93 & 110.67 & 5.01 & 4.52 & 6.75 & 14.64 & 0.16 & 16.66 & 0.05 \\
\hline 62 & $31 / 08 / 2008$ & $01 / 09 / 1429$ & -6.15 & 106.8 & 5.19 & 4.49 & 6.86 & 14.88 & 0.15 & 16.70 & 0.05 \\
\hline 63 & $30 / 09 / 2008$ & $01 / 10 / 1429$ & -7.17 & 112.62 & 9.57 & 4.49 & 10.57 & 14.88 & 0.15 & 17.69 & 0.05 \\
\hline 64 & $17 / 11 / 2009$ & $01 / 12 / 1430$ & -7.17 & 112.62 & 5.81 & 4.67 & 7.46 & 15.21 & 0.17 & 16.84 & 0.06 \\
\hline 65 & $19 / 09 / 2009$ & $01 / 10 / 1430$ & -7.03 & 106.56 & 5.59 & 7.05 & 9.00 & 16.08 & 0.38 & 16.79 & 0.13 \\
\hline 66 & $19 / 09 / 2009$ & $01 / 10 / 1430$ & -6.98 & 110.45 & 5.61 & 6.93 & 8.91 & 15.33 & 0.37 & 16.80 & 0.12 \\
\hline 67 & $17 / 11 / 2009$ & $01 / 12 / 1430$ & -7.17 & 112.62 & 5.81 & 4.67 & 7.46 & 15.21 & 0.17 & 16.84 & 0.06 \\
\hline 68 & $10 / 08 / 2010$ & $01 / 09 / 1431$ & -3.8 & 102.5 & 2.33 & 4.44 & 5.02 & 8.10 & 0.15 & 16.05 & 0.05 \\
\hline 69 & $31 / 10 / 2008$ & $02 / 11 / 1429$ & -6.16 & 106.84 & 24.03 & 27.27 & 13.29 & 59.55 & 5.56 & 20.83 & 2.32 \\
\hline 70 & $29 / 11 / 2008$ & $02 / 12 / 1429$ & -6.16 & 106.84 & 16.99 & 18.50 & 7.43 & 42.00 & 2.58 & 19.33 & 1.00 \\
\hline 71 & $24 / 06 / 2009$ & $03 / 07 / 1430$ & -6.16 & 106.84 & 21.13 & 22.23 & 7.07 & 39.23 & 3.72 & 20.22 & 1.50 \\
\hline 72 & $17 / 03 / 2010$ & $03 / 04 / 1431$ & 5.45 & 95.24 & 13.90 & 18.20 & 11.87 & 38.82 & 2.50 & 18.65 & 0.93 \\
\hline 73 & $16 / 04 / 2010$ & $03 / 05 / 1431$ & -2.55 & 107.72 & 18.61 & 22.68 & 13.20 & 46.42 & 3.86 & 19.68 & 1.52 \\
\hline 74 & $13 / 07 / 2010$ & $03 / 08 / 1431$ & -5.17 & 119.39 & 20.02 & 21.44 & 7.84 & 38.40 & 3.46 & 19.98 & 1.38 \\
\hline 75 & $08 / 08 / 2010$ & $29 / 08 / 1431$ & -8.59 & 116.12 & 25.49 & 29.83 & 16.04 & 52.68 & 6.62 & 21.13 & 2.80 \\
\hline 76 & $11 / 08 / 2010$ & $02 / 09 / 1431$ & -8.40 & 116.08 & 15.45 & 18.06 & 9.47 & 31.13 & 2.46 & 18.99 & 0.93 \\
\hline 77 & $08 / 11 / 2010$ & $03 / 12 / 1431$ & -8.74 & 115.16 & 26.64 & 28.14 & 9.42 & 53.42 & 5.91 & 21.36 & 2.52 \\
\hline 78 & $04 / 02 / 2011$ & $01 / 03 / 1432$ & -0.65 & 119.73 & 10.82 & 14.62 & 9.89 & 31.80 & 1.62 & 17.97 & 0.58 \\
\hline 79 & $05 / 02 / 2011$ & $02 / 03 / 1432$ & -0.65 & 119.73 & 20.89 & 25.40 & 14.78 & 55.80 & 4.83 & 20.17 & 1.95 \\
\hline 80 & $05 / 04 / 2011$ & $03 / 05 / 1432$ & 5.47 & 95.24 & 16.69 & 20.25 & 11.63 & 45.27 & 3.09 & 19.26 & 1.19 \\
\hline 81 & $05 / 05 / 2011$ & $04 / 06 / 1432$ & -7.17 & 112.62 & 19.46 & 23.58 & 13.58 & 51.53 & 4.18 & 19.86 & 1.66 \\
\hline 82 & $03 / 06 / 2011$ & $03 / 07 / 1432$ & -0.06 & 109.17 & 16.77 & 17.74 & 5.87 & 37.70 & 2.38 & 19.28 & 0.92 \\
\hline
\end{tabular}

Copyright (C 2018. Al-Marshad: Jurnal Astronomi Islam dan Ilmu-Ilmu Berkaitan. This is an open acces article under the CC-BY-SA lisence (https://creativecommons.org/licenses/by-sa/4.0/). 
AL-MARSHAD: JURNAL ASTRONOMI ISLAM DAN ILMU-ILMU BERKAITAN

ISSN 2442-5729 (print) || ISSN 2598-2559 (online), http://jurnal.umsu.ac.id/index.php/almarshad DOI: https://doi.org/10.30596/jam.v4i1.1935

Published June 2018

\begin{tabular}{|c|c|c|c|c|c|c|c|c|c|c|c|}
\hline 83 & 02/07/2011 & $03 / 08 / 1432$ & -10.18 & 123.66 & 11.28 & 12.21 & 4.70 & 24.70 & 1.13 & 18.07 & 0.41 \\
\hline 84 & $03 / 07 / 2011$ & $04 / 08 / 1432$ & -10.18 & 123.66 & 24.15 & 25.05 & 6.86 & 48.70 & 4.70 & 20.85 & 1.96 \\
\hline 85 & $29 / 07 / 2011$ & $29 / 08 / 1432$ & -8.74 & 115.18 & 20.48 & 22.87 & 10.41 & 44.10 & 3.93 & 20.08 & 1.58 \\
\hline 86 & $30 / 07 / 2011$ & $30 / 08 / 1432$ & -8.74 & 115.18 & 9.18 & 10.33 & 4.76 & 20.12 & 0.81 & 17.60 & 0.29 \\
\hline 87 & $01 / 08 / 2011$ & $03 / 09 / 1432$ & -8.74 & 115.18 & 20.42 & 22.67 & 10.06 & 39.63 & 3.86 & 20.07 & 1.55 \\
\hline 88 & $28 / 08 / 2011$ & $01 / 10 / 1432$ & -7.03 & 106.56 & 14.11 & 15.69 & 6.93 & 28.13 & 1.86 & 18.70 & 0.70 \\
\hline 89 & $28 / 09 / 2011$ & $02 / 10 / 1432$ & -8.03 & 110.32 & 10.34 & 13.75 & 9.11 & 23.42 & 1.43 & 17.86 & 0.51 \\
\hline 90 & $29 / 09 / 2011$ & $03 / 10 / 1432$ & -8.03 & 110.32 & 24.18 & 27.49 & 13.49 & 47.42 & 5.65 & 20.86 & 2.36 \\
\hline 91 & $28 / 10 / 2011$ & $03 / 11 / 1432$ & -0.86 & 131.26 & 17.80 & 21.06 & 11.44 & 37.10 & 3.34 & 19.50 & 1.30 \\
\hline 92 & $26 / 11 / 2011$ & $01 / 12 / 1432$ & -6.95 & 110.39 & 14.43 & 15.35 & 5.29 & 28.50 & 1.78 & 18.77 & 0.67 \\
\hline 93 & $27 / 11 / 2011$ & $02 / 12 / 1432$ & -6.95 & 110.39 & 27.94 & 28.87 & 7.58 & 52.52 & 6.21 & 21.62 & 2.69 \\
\hline 94 & $20 / 07 / 2012$ & $01 / 09 / 1433$ & -8.74 & 115.18 & 12.63 & 14.71 & 7.60 & 29.88 & 1.64 & 18.37 & 0.60 \\
\hline 95 & $16 / 08 / 2012$ & $28 / 09 / 1433$ & -8.74 & 115.18 & 18.80 & 20.70 & 8.82 & 41.43 & 3.23 & 19.72 & 1.27 \\
\hline 96 & $18 / 08 / 2012$ & $01 / 10 / 1433$ & -8.74 & 115.18 & 6.53 & 10.14 & 7.77 & 18.42 & 0.78 & 17.01 & 0.27 \\
\hline 97 & $16 / 10 / 2012$ & $01 / 12 / 1433$ & -8.74 & 115.18 & 10.08 & 12.04 & 6.62 & 22.22 & 1.10 & 17.80 & 0.39 \\
\hline 98 & $30 / 01 / 2014$ & $01 / 04 / 1435$ & 5.49 & 95.30 & 11.79 & 12.88 & 5.22 & 21.75 & 1.26 & 18.18 & 0.46 \\
\hline 99 & $02 / 03 / 2014$ & $02 / 05 / 1435$ & 1.48 & 124.83 & 10.93 & 14.24 & 9.18 & 25.93 & 1.54 & 17.99 & 0.55 \\
\hline 100 & $30 / 04 / 2014$ & $02 / 07 / 1435$ & -10.15 & 123.61 & 11.40 & 13.23 & 6.76 & 27.37 & 1.33 & 18.10 & 0.48 \\
\hline 101 & $28 / 06 / 2014$ & $02 / 09 / 1435$ & -8.74 & 115.18 & 10.60 & 12.23 & 6.14 & 26.05 & 1.13 & 17.92 & 0.40 \\
\hline 102 & $28 / 06 / 2014$ & $02 / 09 / 1435$ & -5.39 & 119.39 & 10.33 & 12.17 & 6.47 & 25.87 & 1.12 & 17.86 & 0.40 \\
\hline 103 & $28 / 06 / 2014$ & $02 / 09 / 1435$ & -10.15 & 123.61 & 10.47 & 11.96 & 5.81 & 25.45 & 1.09 & 17.89 & 0.39 \\
\hline 104 & $28 / 06 / 2014$ & $02 / 09 / 1435$ & -1.04 & 100.38 & 10.17 & 12.80 & 7.81 & 27.28 & 1.24 & 17.82 & 0.44 \\
\hline 105 & $28 / 06 / 2014$ & $02 / 09 / 1435$ & -1.17 & 136.05 & 9.43 & 11.78 & 7.09 & 24.87 & 1.05 & 17.66 & 0.37 \\
\hline 106 & $28 / 06 / 2014$ & $02 / 09 / 1435$ & 1.47 & 124.83 & 9.67 & 12.18 & 7.44 & 25.68 & 1.12 & 17.71 & 0.40 \\
\hline 107 & $28 / 07 / 2014$ & $03 / 10 / 1435$ & -8.74 & 115.18 & 13.73 & 15.94 & 8.18 & 35.60 & 1.92 & 18.61 & 0.71 \\
\hline 108 & $27 / 08 / 2014$ & $03 / 11 / 1435$ & -6.01 & 106.68 & 17.27 & 19.71 & 9.65 & 43.87 & 2.93 & 19.39 & 1.14 \\
\hline 109 & $25 / 09 / 2014$ & $03 / 12 / 1435$ & -10.14 & 123.62 & 10.60 & 12.00 & 5.66 & 26.07 & 2.93 & 17.92 & 1.05 \\
\hline 110 & $25 / 09 / 2014$ & $03 / 12 / 1435$ & -8.74 & 115.18 & 10.64 & 12.27 & 6.15 & 26.63 & 1.09 & 17.93 & 0.39 \\
\hline 111 & $25 / 09 / 2014$ & $03 / 12 / 1435$ & -8.01 & 110.32 & 10.82 & 12.42 & 6.13 & 26.95 & 1.14 & 17.97 & 0.41 \\
\hline 112 & $25 / 09 / 2014$ & $03 / 12 / 1435$ & -6.06 & 105.90 & 10.92 & 13.00 & 7.10 & 27.23 & 1.17 & 17.99 & 0.42 \\
\hline 113 & $23 / 11 / 2014$ & $02 / 02 / 1436$ & -10.14 & 123.62 & 9.34 & 11.05 & 5.93 & 21.32 & 1.20 & 17.64 & 0.42 \\
\hline 114 & $21 / 01 / 2015$ & $02 / 04 / 1436$ & -7.59 & 107.62 & 8.40 & 12.83 & 9.73 & 22.03 & 0.93 & 17.43 & 0.32 \\
\hline 115 & $20 / 02 / 2015$ & $01 / 05 / 1436$ & 1.55 & 124.82 & 16.45 & 19.44 & 10.51 & 34.17 & 1.25 & 19.21 & 0.48 \\
\hline 116 & $19 / 04 / 2015$ & $01 / 07 / 1436$ & -6.07 & 105.88 & 7.34 & 8.46 & 4.22 & 15.97 & 0.54 & 17.19 & 0.19 \\
\hline 117 & $19 / 04 / 2015$ & $01 / 07 / 1436$ & -5.17 & 119.39 & 6.84 & 7.96 & 4.08 & 15.08 & 0.48 & 17.08 & 0.16 \\
\hline 118 & $19 / 05 / 2015$ & $02 / 08 / 1436$ & -8.65 & 112.73 & 15.0 & 15.97 & 5.54 & 30.07 & 1.93 & 18.89 & 0.73 \\
\hline
\end{tabular}

Copyright (C 2018. Al-Marshad: Jurnal Astronomi Islam dan Ilmu-Ilmu Berkaitan. This is an open acces article under the CC-BY-SA lisence (https://creativecommons.org/licenses/by-sa/4.0/). 
AL-MARSHAD: JURNAL ASTRONOMI ISLAM DAN ILMU-ILMU BERKAITAN

ISSN 2442-5729 (print) || ISSN 2598-2559 (online), http://jurnal.umsu.ac.id/index.php/almarshad DOI: https://doi.org/10.30596/jam.v4i1.1935

Published June 2018

\begin{tabular}{|c|c|c|c|c|c|c|c|c|c|c|c|}
\hline 119 & $17 / 06 / 2015$ & $01 / 09 / 1436$ & 0.78 & 127.31 & 8.25 & 10.38 & 6.32 & 19.53 & 0.82 & 17.39 & 0.29 \\
\hline 120 & $17 / 06 / 2015$ & $01 / 09 / 1436$ & -5.17 & 119.39 & 8.82 & 10.50 & 5.72 & 19.90 & 0.84 & 17.52 & 0.29 \\
\hline 121 & $17 / 06 / 2015$ & $01 / 09 / 1436$ & -10.14 & 123.62 & 8.97 & 10.28 & 5.04 & 19.47 & 0.80 & 17.55 & 0.28 \\
\hline 122 & $17 / 06 / 2015$ & $01 / 09 / 1436$ & -8.74 & 115.18 & 9.07 & 10.57 & 5.45 & 20.07 & 0.85 & 17.58 & 0.30 \\
\hline 123 & $17 / 06 / 2015$ & $01 / 09 / 1436$ & -1.04 & 100.38 & 8.85 & 11.17 & 6.84 & 21.30 & 0.95 & 17.53 & 0.33 \\
\hline 124 & $14 / 09 / 2015$ & $02 / 12 / 1436$ & 0.78 & 127.31 & 9.35 & 11.28 & 6.34 & 26.82 & 0.97 & 17.64 & 0.34 \\
\hline 125 & $14 / 09 / 2015$ & $02 / 12 / 1436$ & -3.58 & 128.08 & 9.64 & 12.23 & 7.56 & 26.75 & 0.96 & 17.71 & 0.34 \\
\hline 126 & $14 / 09 / 2015$ & $02 / 12 / 1436$ & 1.55 & 124.82 & 9.25 & 11.37 & 6.64 & 27.00 & 0.98 & 17.62 & 0.35 \\
\hline 127 & $14 / 09 / 2015$ & $02 / 12 / 1436$ & -5.17 & 119.39 & 9.93 & 11.48 & 5.79 & 27.33 & 1.00 & 17.77 & 0.36 \\
\hline 128 & $14 / 09 / 2015$ & $02 / 12 / 1436$ & -10.14 & 123.62 & 10.10 & 11.32 & 5.14 & 27.03 & 0.97 & 17.81 & 0.35 \\
\hline 129 & $14 / 09 / 2015$ & $02 / 12 / 1436$ & -8.74 & 115.18 & 10.16 & 11.59 & 5.61 & 27.60 & 1.02 & 17.82 & 0.36 \\
\hline 130 & $14 / 09 / 2015$ & $02 / 12 / 1436$ & -6.70 & 106.93 & 9.48 & 11.87 & 7.18 & 28.22 & 1.07 & 17.67 & 0.38 \\
\hline 131 & $14 / 10 / 2015$ & $02 / 01 / 1437$ & -8.16 & 112.45 & 13.62 & 15.03 & 6.42 & 34.35 & 1.71 & 18.59 & 0.64 \\
\hline 132 & $14 / 10 / 2015$ & $02 / 01 / 1437$ & -7.59 & 107.62 & 14.20 & 15.16 & 5.36 & 34.63 & 1.74 & 18.72 & 0.65 \\
\hline 133 & $11 / 11 / 2015$ & $01 / 02 / 1437$ & 0.83 & 127.38 & 6.40 & 9.35 & 6.83 & 20.60 & 0.66 & 16.98 & 0.22 \\
\hline 134 & $12 / 12 / 2015$ & $02 / 03 / 1437$ & 0.80 & 127.29 & 9.98 & 11.59 & 5.92 & 22.95 & 1.02 & 17.78 & 0.36 \\
\hline 135 & $12 / 12 / 2015$ & $02 / 03 / 1437$ & 1.55 & 124.82 & 9.98 & 11.66 & 6.06 & 23.12 & 1.03 & 17.78 & 0.37 \\
\hline 136 & $12 / 12 / 2015$ & $02 / 03 / 1437$ & -10.14 & 123.62 & 9.08 & 11.93 & 7.77 & 23.53 & 1.08 & 17.58 & 0.38 \\
\hline
\end{tabular}

adalah beda azimut hilal-matahari

Kolom pertama adalah nomor data, kolom kedua adalah tanggal pengamatan hilal dalam kalender Masehi, kolom ketiga adalah tanggal pengamatan hilal dalam kalender Hijriah, kolom keempat dan kelima adalah koordinat lokasi pengamatan hilal dinyatakan dalam derajat desimal, kolom keenam adalah ketinggian toposentrik hilal dinyatakan dalam derajat desimal, kolom ketujuh adalah elongasi atau busur cahaya (arc of light, ArcL) hilal-matahari dinyatakan dalam derajat desimal, kolom kedelapan
(DAz) dinyatakan dalam derajat desimal, kolom kesembilan adalah umur hilal dihitung sejak ijtimak dinyatakan dalam jam desimal, kolom kesepuluh adalah fraksi iluminasi dinyatakan dalam persentase, kolom kesebelas adalah semidiameter hilal toposentrik dinyatakan dalam menit busur dan kolom keduabelas adalah lebar cahaya hilal toposentrik dinyatakan dalam menit busur.

Berdasarkan tabel 1, penulis menyarikan nilai maksimum dan 
minimum dari tiap-tiap parameter ke

dalam tabel berikut ini :

Tabel 2 Nilai maksimum dan minimum dari tiap-tiap parameter

\begin{tabular}{|l|r|r|r|r|r|r|l|}
\cline { 2 - 8 } \multicolumn{1}{c|}{} & \multicolumn{1}{c|}{ H } & ARCL & \multicolumn{1}{c|}{ DAZ } & AGE & FI & \multicolumn{1}{c|}{ SD' $^{\prime}$} & W' $^{\prime}$ \\
\hline maksimum & $27.94^{\circ}$ & $29.83^{\circ}$ & $16.04^{\circ}$ & $59.55 \mathrm{jam}$ & $6.62 \%$ & $21.62^{\prime}$ & $2.80^{\prime}$ \\
\hline minimum & $2.08^{\circ}$ & $0.09^{\circ}$ & $0.31^{\circ}$ & $7.62 \mathrm{jam}$ & $0.00 \%$ & $16.00^{\prime}$ & $0.00^{\prime}$ \\
\hline
\end{tabular}

Nilai persentase fraksi iluminasi dan lebar cahaya hilal toposentrik pada tabel yang bernilai nol sebenarnya tidak benar-benar nol namun karena dibulatkan hingga dua angka di belakang koma, sehingga kedua nilai tersebut bernilai nol. Terlihat pada tabel tersebut, rentang ketinggian toposentrik sebesar $25,86^{\circ}$, elongasi $29,74^{\circ}$, selisih azimut $15,73^{\circ}$, umur hilal 41,93 jam, fraksi iluminasi 6,62\%, semidiameter 5,62' dan lebar toposentrik 2,8'. Rentang yang cukup besar ini dikarenakan pengamatan yang tidak hanya dilakukan ketika magrib hari ijtimak namun dua bahkan tiga hari setelahnya. Posisi dan keadaan hilal dapat dilihat dari aspek ketinggian toposentrik dan semidiameter toposentrik, elongasi, selisih azimut, umur hilal, fraksi iluminasi dan lebar hilal. Perubahan masing-masing parameter dibandingkan dengan parameter lainnya dapat dilihat pada gambar berikut ini. Grafik dibuat dengan SPSS 16.0.

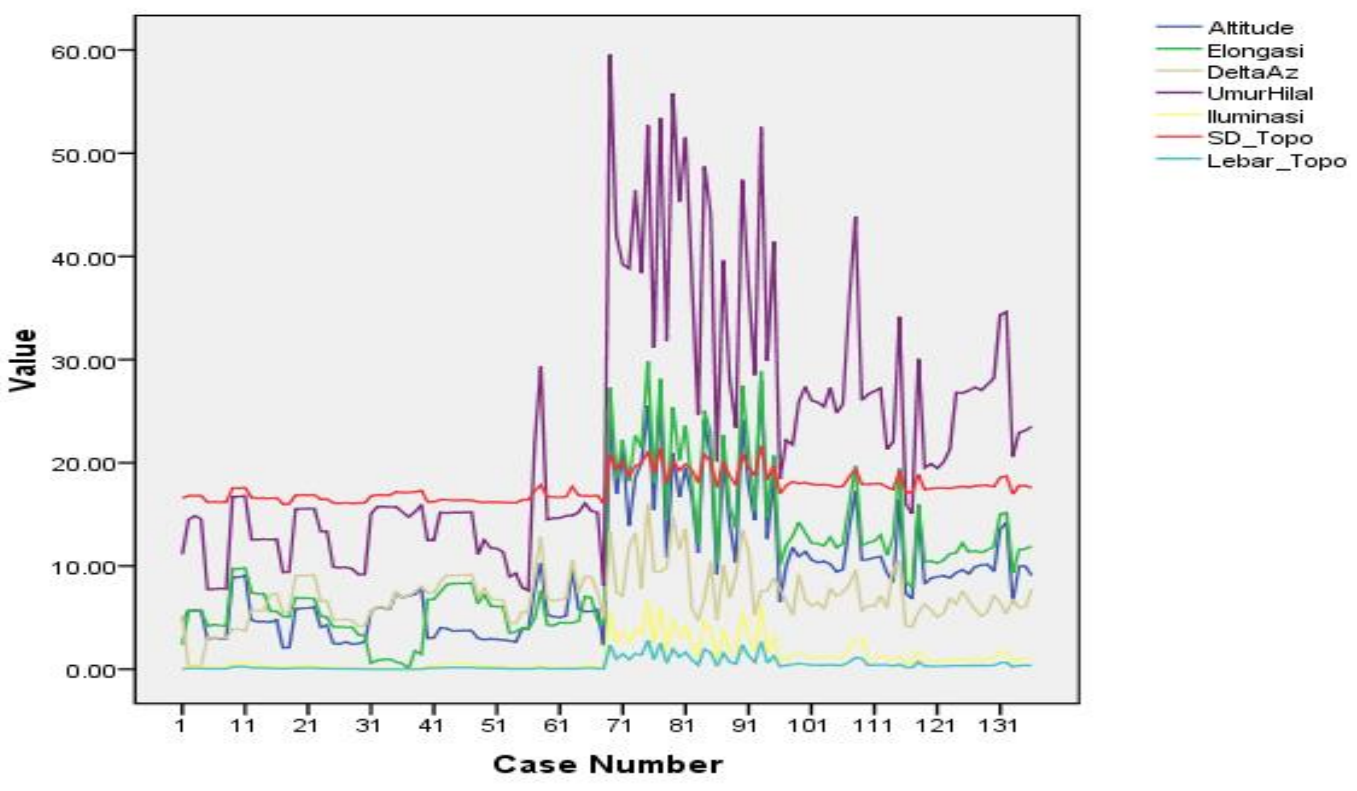

Gambar 2 Keadaan Hilal dilihat dari berbagai parameter visibilitas hilal

Terlihat pada grafik gambar 2 di memiliki keterkaitan. Ketika nilai salah atas, bahwa tiap-tiap parameter satu parameter naik, maka nilai 
Published June 2018

parameter yang lain juga akan ikut naik, sebaliknya jika nilai salah satu parameter turun. maka nilai parameter yang lain juga akan ikut turun. Namun untuk grafik selisih azimut dan elongasi tidak ditemukan kekonsistenan data hingga data keempat puluh, ketika ketinggian hilal naik, ada data di mana selisih azimut dan elongasi justru turun. Dapat diperoleh kesimpulan bahwa azimut dan elongasi memiliki karakteristik yang berbeda dengan parameter-parameter yang lain.
Pengujian perbedaan karakter dari masing-masing parameter dapat dilihat pada grafik berikut ini. Pada grafik berikut, penulis menunjukkan hubungan masing-masing parameter diantaranya: ketinggian toposentrik dengan elongasi, ketinggian toposentrik dengan selisih azimut, ketinggian topsentrik dengan lebar hilal, elongasi dengan selisih azimut, lebar hilal dengan umur hilal, dan semidiameter toposentrik dengan fraksi iluminasi hilal. Grafik dibuat memggunakan SPSS 16.0.

Altitude

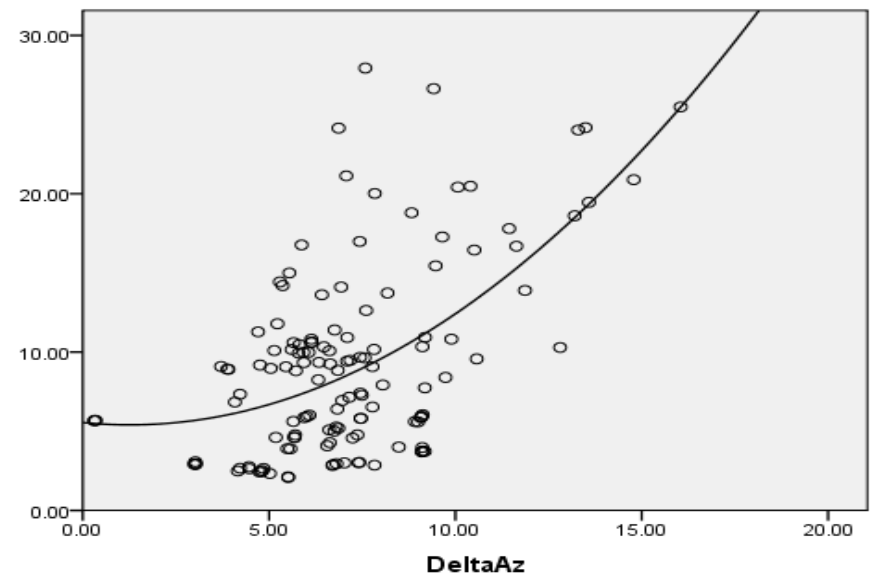

$\circ$ Observed

Gambar 3 Hubungan Selisih Azimut dengan Altitude Toposentrik

Tabel 3 Ringkasan Pemodelan Regresi antara Selisih Azimut dengan Altitude Toposentrik

\begin{tabular}{|r|r|r|r|}
\multicolumn{5}{|c|}{ Model Summary } \\
\hline $\mathrm{R}$ & $\mathrm{R}$ Square & $\begin{array}{c}\text { Adjusted R } \\
\text { Square }\end{array}$ & $\begin{array}{c}\text { Std. Error of the } \\
\text { Estimate }\end{array}$ \\
\hline .564 & .318 & .308 & 4.948 \\
\hline
\end{tabular}

The independent variable is DeltaAz.

Tabel 4 Koefisien Regresi antara Selisih Azimut dengan Altitude Toposentrik Coefficients 
AL-MARSHAD: JURNAL ASTRONOMI ISLAM DAN ILMU-ILMU BERKAITAN

ISSN 2442-5729 (print) || ISSN 2598-2559 (online), http://jurnal.umsu.ac.id/index.php/almarshad DOI: https://doi.org/10.30596/jam.v4i1.1935

Published June 2018

\begin{tabular}{|l|r|r|r|r|r|}
\hline & \multicolumn{2}{|c|}{ Unstandardized Coefficients } & \multicolumn{1}{c|}{$\begin{array}{c}\text { Standardized } \\
\text { Coefficients }\end{array}$} & \\
\cline { 2 - 4 } & $\mathrm{B}$ & Std. Error & \multicolumn{1}{|c|}{ Beta } & \multicolumn{1}{c|}{ Sig. } \\
\hline DeltaAz & -.231 & .578 & -.102 & -.399 & .690 \\
DeltaAz ${ }^{* *} 2$ & .092 & .035 & .661 & 2.598 & .010 \\
(Constant) & 5.549 & 2.271 & & 2.444 & .016 \\
\hline
\end{tabular}

\section{Elongasi}

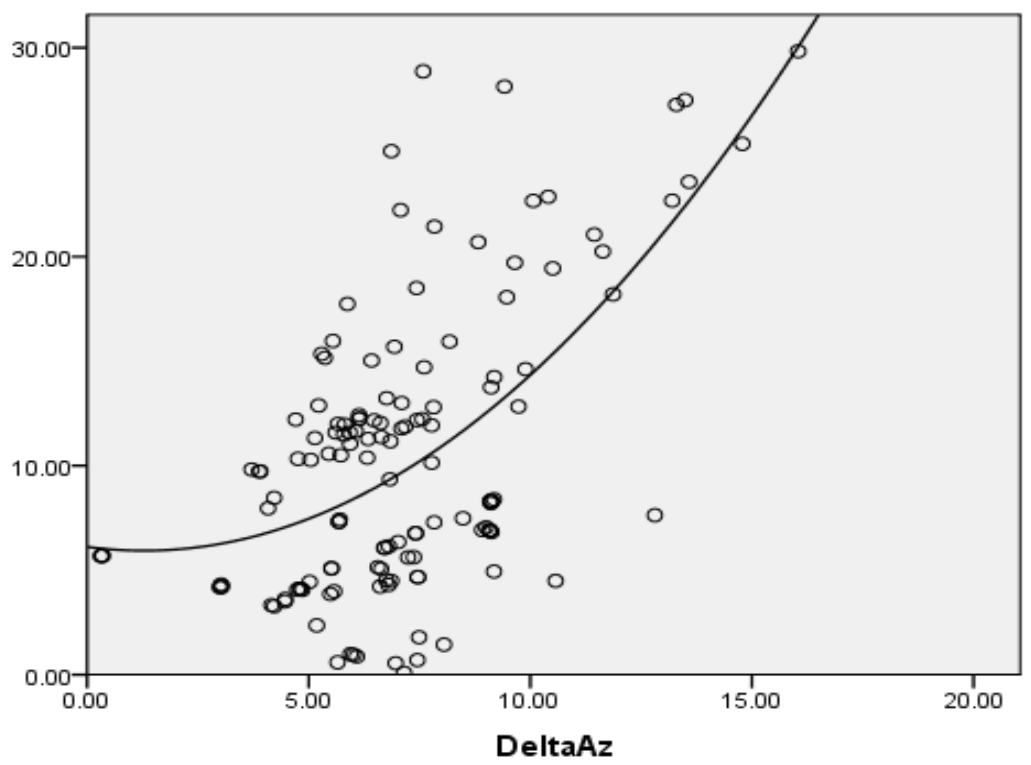

Gambar 4 Hubungan Selisih Azimut dengan Elongasi

Tabel 5 Ringkasan Pemodelan Regresi antara Selisih Azimut dengan Elongasi

\begin{tabular}{|r|r|r|r|}
\multicolumn{4}{|c|}{ Model Summary } \\
\hline R & R Square & $\begin{array}{c}\text { Adjusted R } \\
\text { Square }\end{array}$ & $\begin{array}{c}\text { Std. Error of the } \\
\text { Estimate }\end{array}$ \\
\hline .593 & .352 & .342 & 5.511 \\
\hline
\end{tabular}

The independent variable is DeltaAz. 
AL-MARSHAD: JURNAL ASTRONOMI ISLAM DAN ILMU-ILMU BERKAITAN

ISSN 2442-5729 (print) || ISSN 2598-2559 (online), http://jurnal.umsu.ac.id/index.php/almarshad DOI: https://doi.org/10.30596/jam.v4i1.1935

Published June 2018

Tabel 6 Koefisien Regresi antara Selisih Azimut dengan Elongasi

Coefficients

\begin{tabular}{|l|r|r|r|r|r|}
\hline & \multicolumn{2}{|c|}{ Unstandardized Coefficients } & $\begin{array}{c}\text { Standardized } \\
\text { Coefficients }\end{array}$ & \\
\cline { 2 - 4 } & $\mathrm{B}$ & Std. Error & Beta & $\mathrm{t}$ & \multicolumn{1}{|c|}{ Sig. } \\
\hline DeltaAz & -.283 & .643 & -.109 & -.440 & .661 \\
DeltaAz ${ }^{* *} 2$ & .111 & .039 & .697 & 2.812 & .006 \\
(Constant) & 6.114 & 2.529 & & 2.418 & .017 \\
\hline
\end{tabular}

Altitude

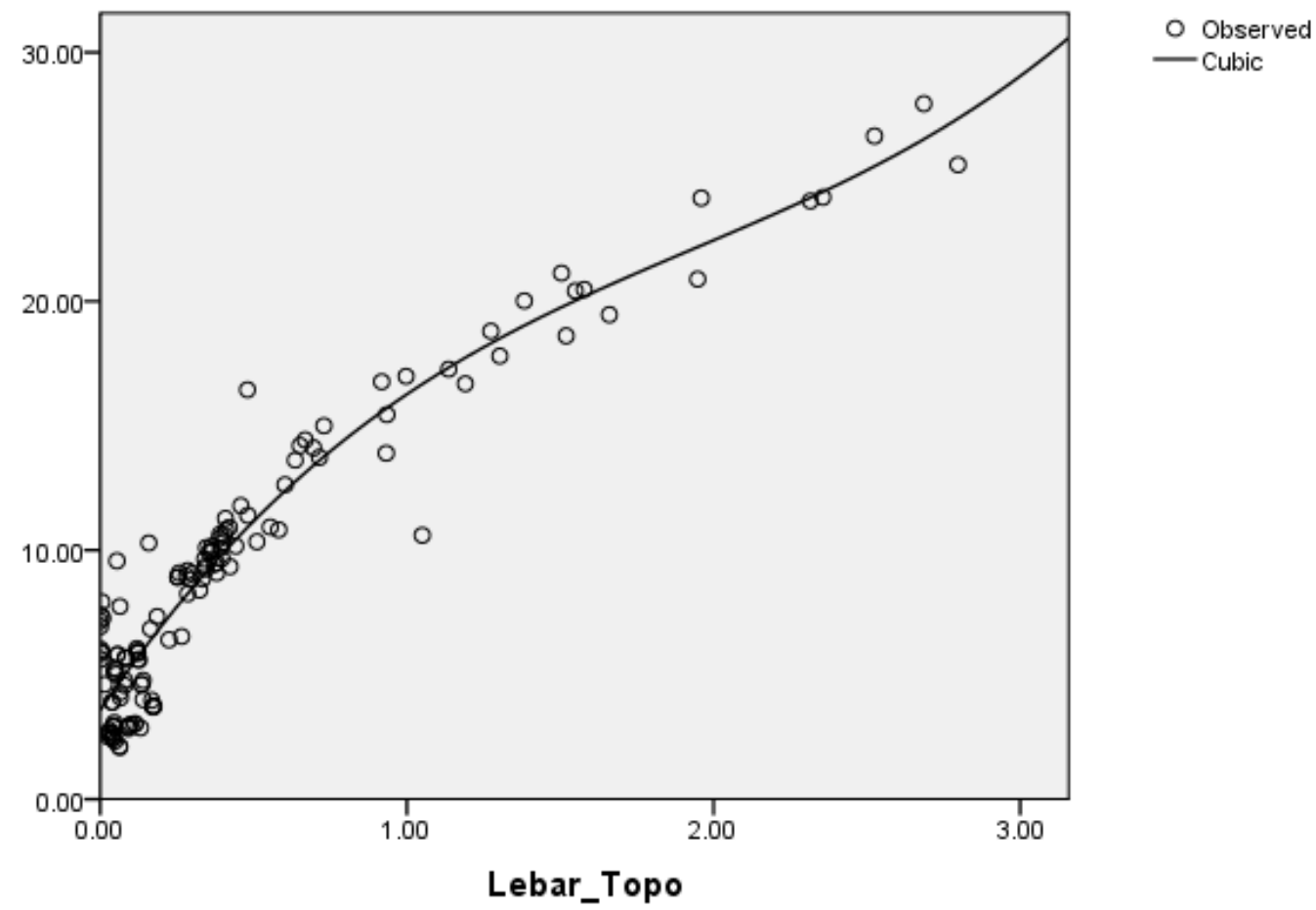

Gambar 5 Hubungan Lebar Hilal dengan Altitude Toposentrik

Tabel 7 Ringkasan Pemodelan Regresi antara Lebar Hilal dengan Altitude Toposentrik

\begin{tabular}{|r|r|r|r|}
\multicolumn{5}{|c|}{ Model Summary } \\
\hline $\mathrm{R}$ & $\mathrm{R}$ Square & $\begin{array}{c}\text { Adjusted R } \\
\text { Square }\end{array}$ & $\begin{array}{c}\text { Std. Error of the } \\
\text { Estimate }\end{array}$ \\
\hline .956 & .915 & .913 & 1.758 \\
\hline
\end{tabular}

The independent variable is Lebar_Topo. 
AL-MARSHAD: JURNAL ASTRONOMI ISLAM DAN ILMU-ILMU BERKAITAN

ISSN 2442-5729 (print) || ISSN 2598-2559 (online), http://jurnal.umsu.ac.id/index.php/almarshad DOI: https://doi.org/10.30596/jam.v4i1.1935

Published June 2018

Tabel 8 Koefisien Regresi antara Lebar Hilal dengan Altitude Toposentrik

Coefficients

\begin{tabular}{|c|c|c|c|c|c|}
\hline & \multicolumn{2}{|c|}{ Unstandardized Coefficients } & \multirow{2}{*}{$\begin{array}{c}\begin{array}{c}\text { Standardized } \\
\text { Coefficients }\end{array} \\
\text { Beta }\end{array}$} & \multirow[b]{2}{*}{$\mathrm{t}$} & \multirow[b]{2}{*}{ Sig. } \\
\hline & $\mathrm{B}$ & Std. Error & & & \\
\hline Lebar_Topo & 18.253 & 1.523 & 1.824 & 11.985 & .000 \\
\hline Lebar_Topo ** 2 & -6.711 & 1.656 & -1.541 & -4.052 & .000 \\
\hline Lebar_Topo ** 3 & 1.153 & .450 & .649 & 2.560 & .012 \\
\hline (Constant) & 3.572 & .275 & & 12.985 & .000 \\
\hline
\end{tabular}

\section{Altitude}

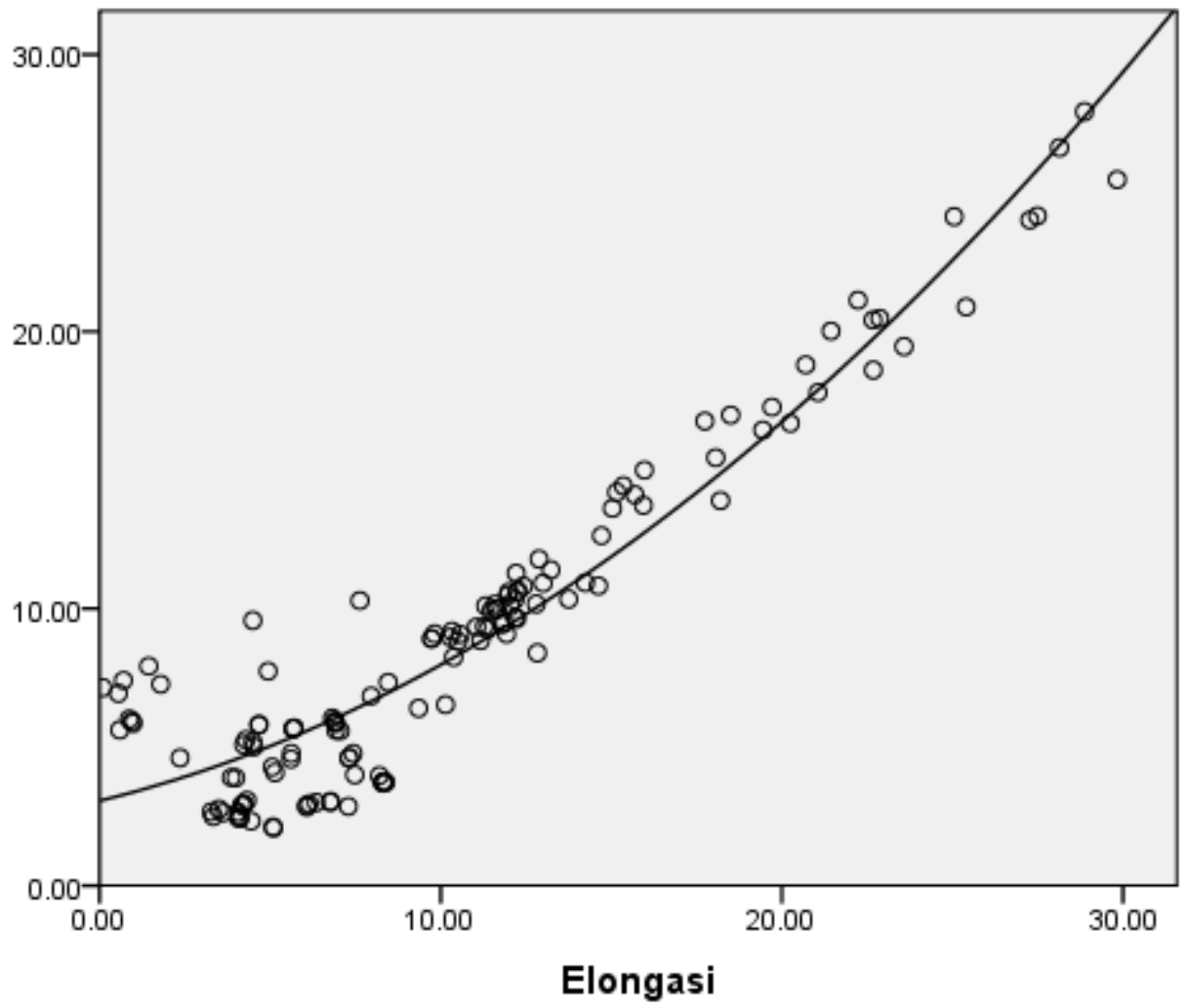

O Observed - Quadratic

Gambar 6 Hubungan Elongasi dengan Altitude Toposentrik

Tabel 9 Ringkasan Pemodelan Regresi antara Elongasi dengan Altitude Toposentrik

\begin{tabular}{|r|r|r|r|}
\hline \multicolumn{5}{|c|}{ Model Summary } \\
\hline $\mathrm{R}$ & $\mathrm{R}$ Square & $\begin{array}{c}\text { Adjusted R } \\
\text { Square }\end{array}$ & $\begin{array}{c}\text { Std. Error of the } \\
\text { Estimate }\end{array}$ \\
\hline .952 & .907 & .905 & 1.831 \\
\hline
\end{tabular}


AL-MARSHAD: JURNAL ASTRONOMI ISLAM DAN ILMU-ILMU BERKAITAN

ISSN 2442-5729 (print) || ISSN 2598-2559 (online), http://jurnal.umsu.ac.id/index.php/almarshad DOI: https://doi.org/10.30596/jam.v4i1.1935

Published June 2018

\begin{tabular}{|r|r|r|r|}
\hline \multicolumn{2}{|c|}{ Model Summary } \\
\hline $\mathrm{R}$ & $\mathrm{R}$ Square & $\begin{array}{c}\text { Adjusted R } \\
\text { Square }\end{array}$ & $\begin{array}{c}\text { Std. Error of the } \\
\text { Estimate }\end{array}$ \\
\hline .952 & .907 & .905 & 1.831 \\
\hline
\end{tabular}

The independent variable is Elongasi.

Tabel 10 Koefisien Regresi antara Elongasi dengan Altitude Toposentrik

\begin{tabular}{|c|c|c|c|c|c|}
\hline \multicolumn{6}{|c|}{ Coefficients } \\
\hline & \multicolumn{2}{|c|}{ Unstandardized Coefficients } & \multirow{2}{*}{$\begin{array}{c}\begin{array}{c}\text { Standardized } \\
\text { Coefficients }\end{array} \\
\text { Beta }\end{array}$} & \multirow[b]{2}{*}{$\mathrm{t}$} & \multirow[b]{2}{*}{ Sig. } \\
\hline & B & Std. Error & & & \\
\hline Elongasi & .298 & .079 & .340 & 3.761 & .000 \\
\hline Elongasi ** 2 & .019 & .003 & .622 & 6.871 & .000 \\
\hline (Constant) & 3.065 & .457 & & 6.709 & .000 \\
\hline
\end{tabular}

\section{Iluminasi}

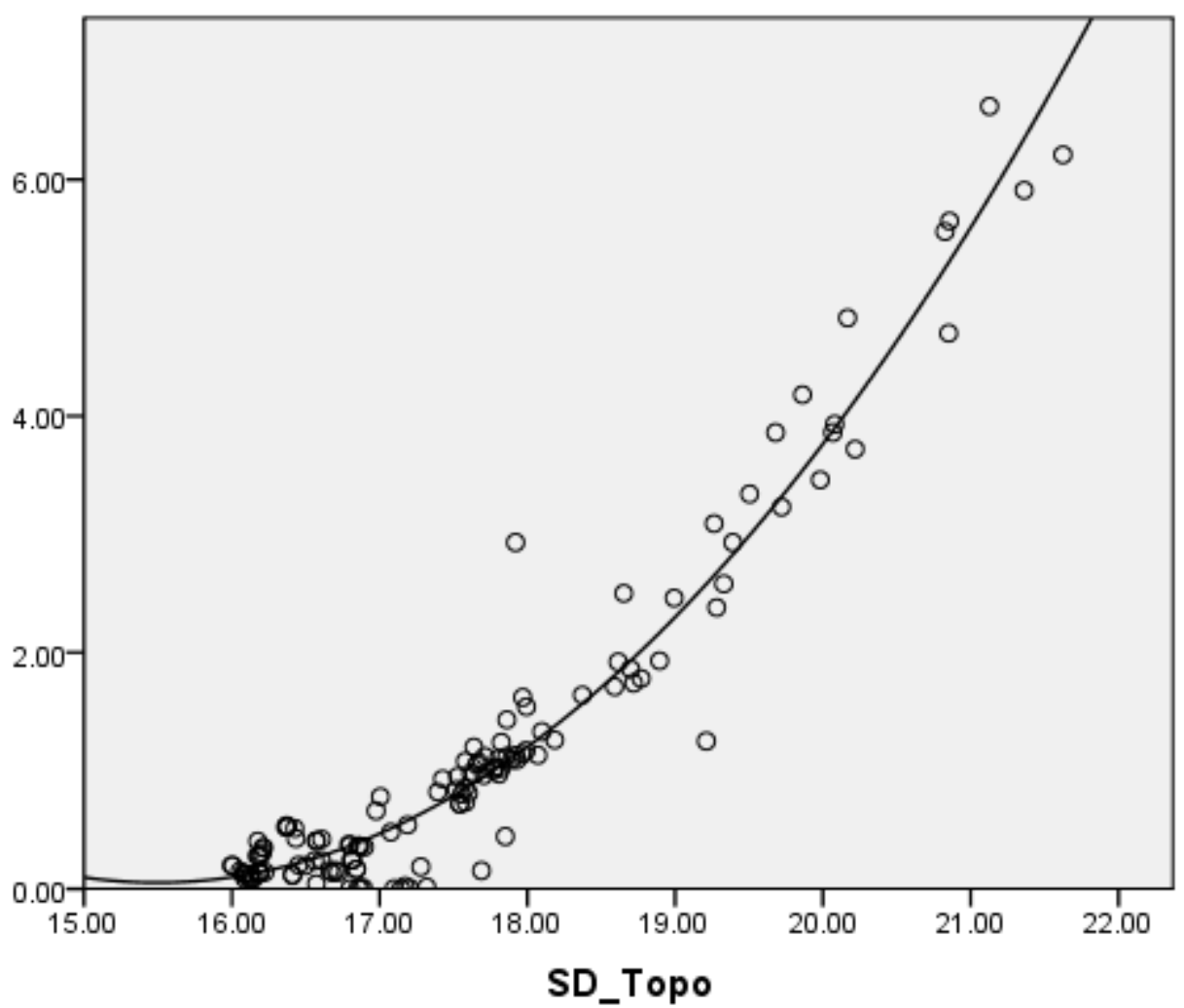

O Observed - Quadratic

Gambar 7 Hubungan Semidiameter Toposentrik dengan Fraksi Iluminasi 
Tabel 11 Ringkasan Pemodelan Regresi antara Semidiameter Toposentrik dengan Fraksi Iluminasi

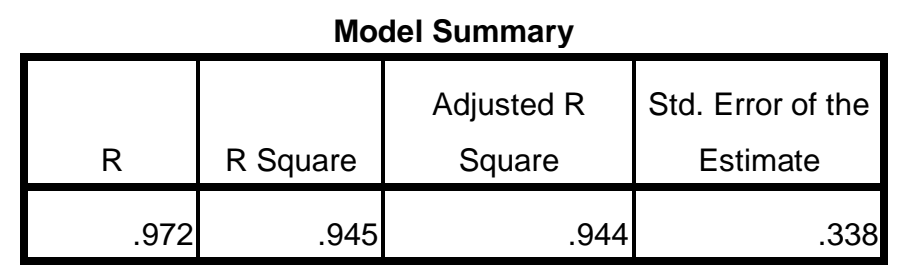

The independent variable is SD_Topo.

Tabel 12 Koefisien Regresi antara Semidiameter Toposentrik dengan Fraksi Iluminasi

\begin{tabular}{|c|c|c|c|c|c|}
\hline \multicolumn{6}{|c|}{ Coefficients } \\
\hline & \multicolumn{2}{|c|}{ Unstandardized Coefficients } & \multirow{2}{*}{$\begin{array}{c}\text { Standardized } \\
\text { Coefficients }\end{array}$} & \multirow[b]{2}{*}{$\mathrm{t}$} & \multirow[b]{2}{*}{ Sig. } \\
\hline & B & Std. Error & & & \\
\hline SD_Topo & -5.663 & .516 & -5.184 & -10.982 & .000 \\
\hline SD_Topo ** 2 & .183 & .014 & 6.125 & 12.977 & .000 \\
\hline (Constant) & 43.919 & 4.696 & & 9.352 & .000 \\
\hline
\end{tabular}

\section{UmurHilal}

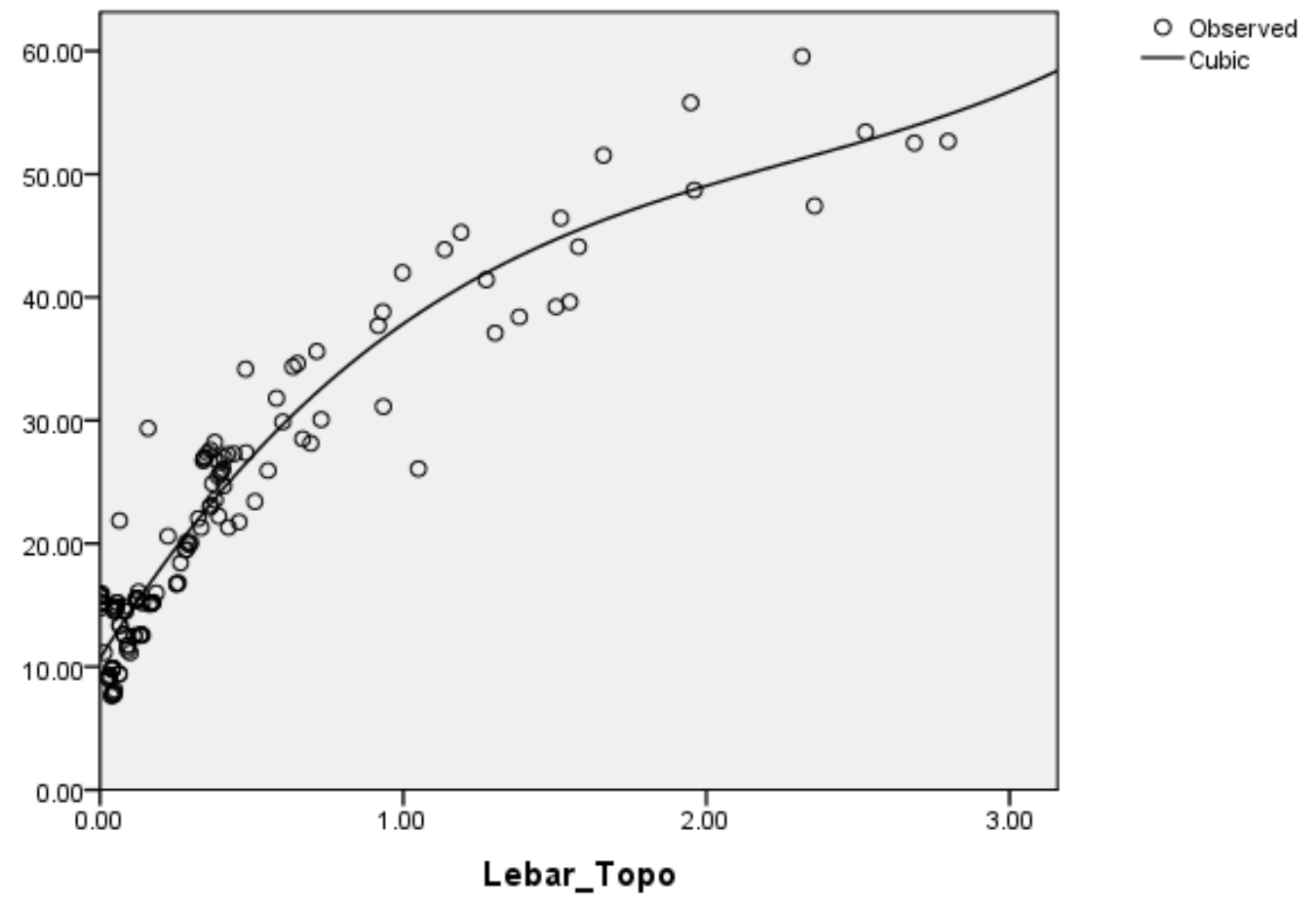

Gambar 8 Hubungan Lebar Hilal dengan Umur Hilal 
Tabel 13 Ringkasan Pemodelan Regresi antara Lebar Hilal dengan Umur Hilal

\begin{tabular}{|r|r|r|r|}
\multicolumn{5}{|c|}{ Model Summary } \\
\hline $\mathrm{R}$ & $\mathrm{R}$ Square & $\begin{array}{c}\text { Adjusted R } \\
\text { Square }\end{array}$ & $\begin{array}{c}\text { Std. Error of the } \\
\text { Estimate }\end{array}$ \\
\hline .955 & .912 & .910 & 3.632 \\
\hline
\end{tabular}

The independent variable is Lebar_Topo.

Tabel 14 Koefisien Regresi antara Lebar Hilal dengan Umur Hilal

Coefficients

\begin{tabular}{|l|r|r|r|r|r|}
\hline & \multicolumn{2}{|c|}{$\begin{array}{c}\text { Standardized } \\
\text { Unstandardized Coefficients }\end{array}$} & \multicolumn{2}{|c|}{ Coefficients } & \multicolumn{1}{c|}{} \\
\cline { 2 - 4 } & \multicolumn{1}{|c|}{$\mathrm{B}$} & Std. Error & \multicolumn{1}{c|}{ Beta } & \multicolumn{1}{c|}{ Sig. } \\
\hline Lebar_Topo & 39.290 & 3.146 & 1.934 & 12.489 & .000 \\
Lebar_Topo ** 2 & -14.189 & 3.421 & -1.604 & -4.148 & .000 \\
Lebar_Topo ** 3 & 2.069 & .930 & .574 & 2.225 & .028 \\
(Constant) & 10.676 & .568 & & 18.791 & .000 \\
\hline
\end{tabular}

Terlihat dari tabel dan grafik bahwa koefisien determinasi dari tiaptiap grafik bervariasi. Koefisien determinasi dalam sebuah regresi $\left(R^{2}\right)$ menyatakan seberapa dekat jarak antara data dengan kurva regresinya. Semakin banyak data yang berdekatan dengan kurva regresi, semakin besar pula koefisien determinasinya. Nilai koefisien determinasi maksimum 1 berarti setiap data dari 1 variabel saling memengaruhi variabel lain secara tepat, sedangkan nilai koefisien determinasi minimum 0 berarti setiap data dari 1 variabel tidak begitu signifikan mempengaruhi variabel yang lain. Koefisien determinasi terbesar diperoleh dari hubungan semidiameter toposentrik dengan fraksi iluminasi bernilai 0,945; disusul kemudian altitude toposentrik dengan lebar hilal bernilai 0,915 ; lebar hilal-elongasi bernilai $\quad 0,912 ; \quad$ elongasi-altitude toposentrik bernilai 0,9066 dan nilai koefisien terendah diperoleh dari hubungan selisih azimut dengan altitude toposentrik dan elongasi berturutberturut bernilai 0,352 dan 0,318 . Berdasarkan nilai koefisien determinasi ini juga terlihat bahwa azimut tidak begitu signifikan mempengaruhi altitude toposentrik dan elongasi karena nilai koefisien yang rendah. Namun di sisi lain, lebar hilal, umur hilal elongasi 
dan ketinggian hilal saling memengaruhi satu sama lain dengan begitu signifikan karena nilai koefisien yang cukup besar mendekati 1 .

\section{Pembentukan Kriteria Visibilitas Hilal}

Penentuan koefisien determinasi dan koefisien korelasi untuk tiap-tiap variabel visibilitas hilal hanya digunakan untuk mencari hubungan seberapa signifikan variabel tersebut dengan variabel lainnya. Selain itu juga, persamaan regresi yang telah di bentuk hanya digunakan untuk mengestimasi nilai suatu data yang tidak ada di dalam data yang diketahui, baik dengan interpolasi (data berada di dalam beberapa nilai data yang diketahui) maupun ekstrapolasi (data berada di luar beberapa nilai data yang diketahui). Namun ketiganya tidak mampu menentukan apakah hilal dapat terlihat ataupun tidak. Untuk itulah, pembentukan kriteria visibiltias hilal dilakukan berdasarkan oleh batas-batas minimum dari hubungan dua variabel visibilitas hilal yang mana jika dibuat suatu fungsi atau persamaan, fungsi tersebut akan melewati titik-titik terluar (outlier) dari berbagai data. Dalam menentukan variabel mana saja yang dapat dibuat kriteria visibilitas hilal, penulis melakukan pembentukan kriteria visibilitas hilal berdasarkan hubungan faktor-faktor yang dapat mendukung visibilitas hilal secara umum yakni parameter empiris bulan (berkaitan dengan posisi hilal dan matahari seperti ketinggian, azimut dan elongasi) dan parameter fisis bulan (berkaitan dengan besaran yang dapat terlihat secara fisis pada bulan seperti lebar hilal, kecerlangan, kontras, sudut fase, iluminasi). Selain itu juga, signifikansi hubungan antar parameter juga menjadi pertimbangan penulis dalam menentukan variabel mana saja yang digunakan dalam pembentukan kriteria visibilitas ini. Sehingga, formulasi kriteria visibilitas hilal yang penulis angkat disini terdiri dari variabel berikut:

- Altitude toposentrik dengan Selisih Azimut (karena keduanya tidak memiliki hubungan yang signifikan dan kecenderungan yang berbeda sehingga perlu dianalsis pergerakannya).

- Altitude toposentrik dengan Elongasi dan 
AL-MARSHAD: JURNAL ASTRONOMI ISLAM DAN ILMU-ILMU BERKAITAN

ISSN 2442-5729 (print) || ISSN 2598-2559 (online), http://jurnal.umsu.ac.id/index.php/almarshad DOI: https://doi.org/10.30596/jam.v4i1.1935

Published June 2018

- Altitude toposentrik dengan lebar hilal toposentrik.

ketiga variabel ini (altitude toposentrik, elongasi dan lebar hilal) memiliki hubungan yang cukup signifikan dan independen terhadap variabel yang lain.

Dalam menentukan kurva batas terlebih dahulu menentukan titik-titik terluar (outlier) dari sekumpulan data pada hubungan antar dua variabel sehingga, data-data yang lain berada di dalam lingkup kurva yang melewati titik-titik terluar tersebut. Berikut ini data outlier untuk masing-masing hubungan antar dua variabel:

minimum kriteria visibilitas hilal,

Tabel 16 Titik-titik terluar (outlier) hubungan antar dua variabel visibilitas hilal

\begin{tabular}{|c|c|}
\hline DAZ & $H$ \\
\hline 3.02 & 2.89 \\
\hline 4.16 & 2.49 \\
\hline 5.51 & 2.08 \\
\hline 9.18 & 3.73 \\
\hline
\end{tabular}

\begin{tabular}{|c|c|}
\hline ARCL & H \\
\hline 3.33 & 2.49 \\
\hline 5.10 & 2.08 \\
\hline 29.83 & 25.49 \\
\hline
\end{tabular}

\begin{tabular}{|c|c|}
\hline $\mathrm{W}^{\prime}$ & $\mathrm{H}$ \\
\hline 0.06 & 2.12 \\
\hline 0.13 & 2.86 \\
\hline 1.05 & 10.60 \\
\hline 2.80 & 25.49 \\
\hline
\end{tabular}

Berikut ini grafik kriteria visibilitas hilal. Grafik ini dibuat dengan SPSS 16.0.

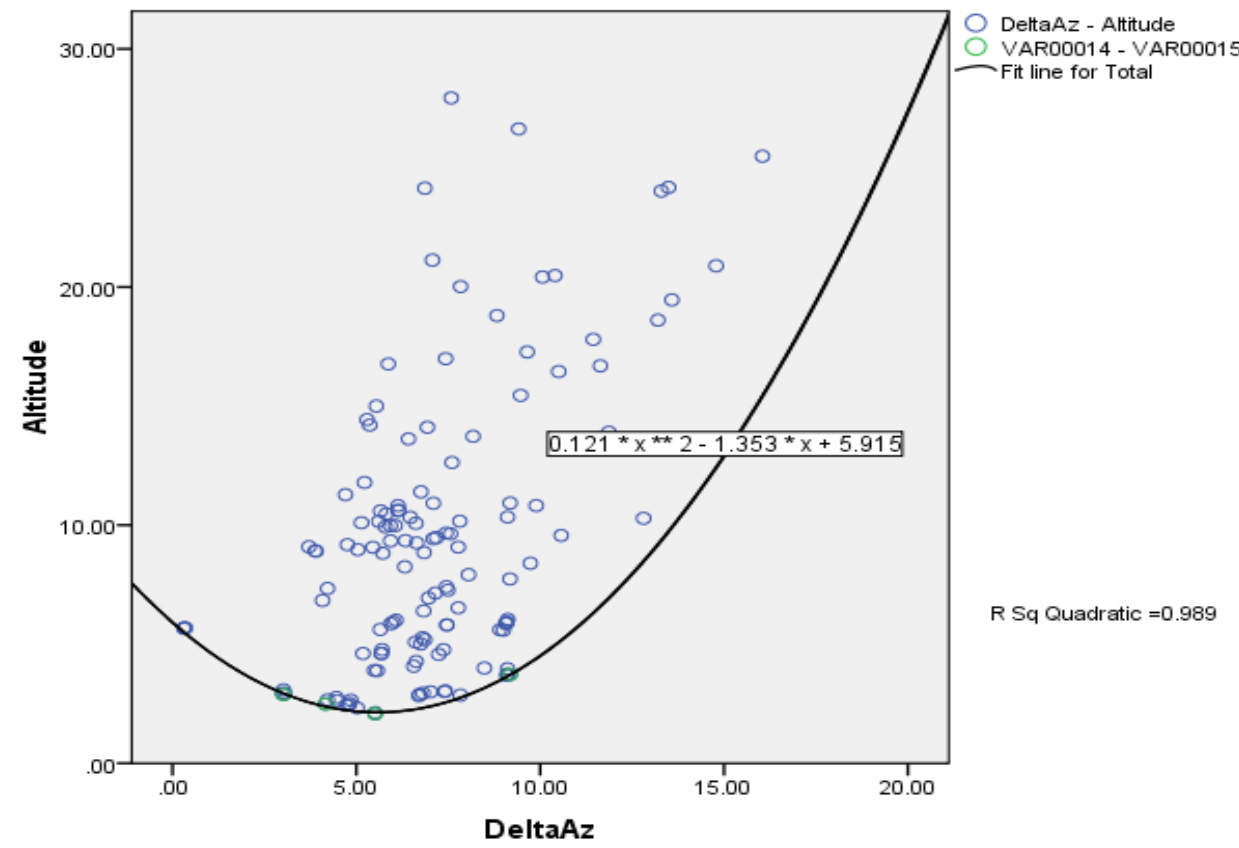

Gambar 5 Kriteria Visibilitas Hilal, Altitude - Selisih Azimut 


\section{Published June 2018}

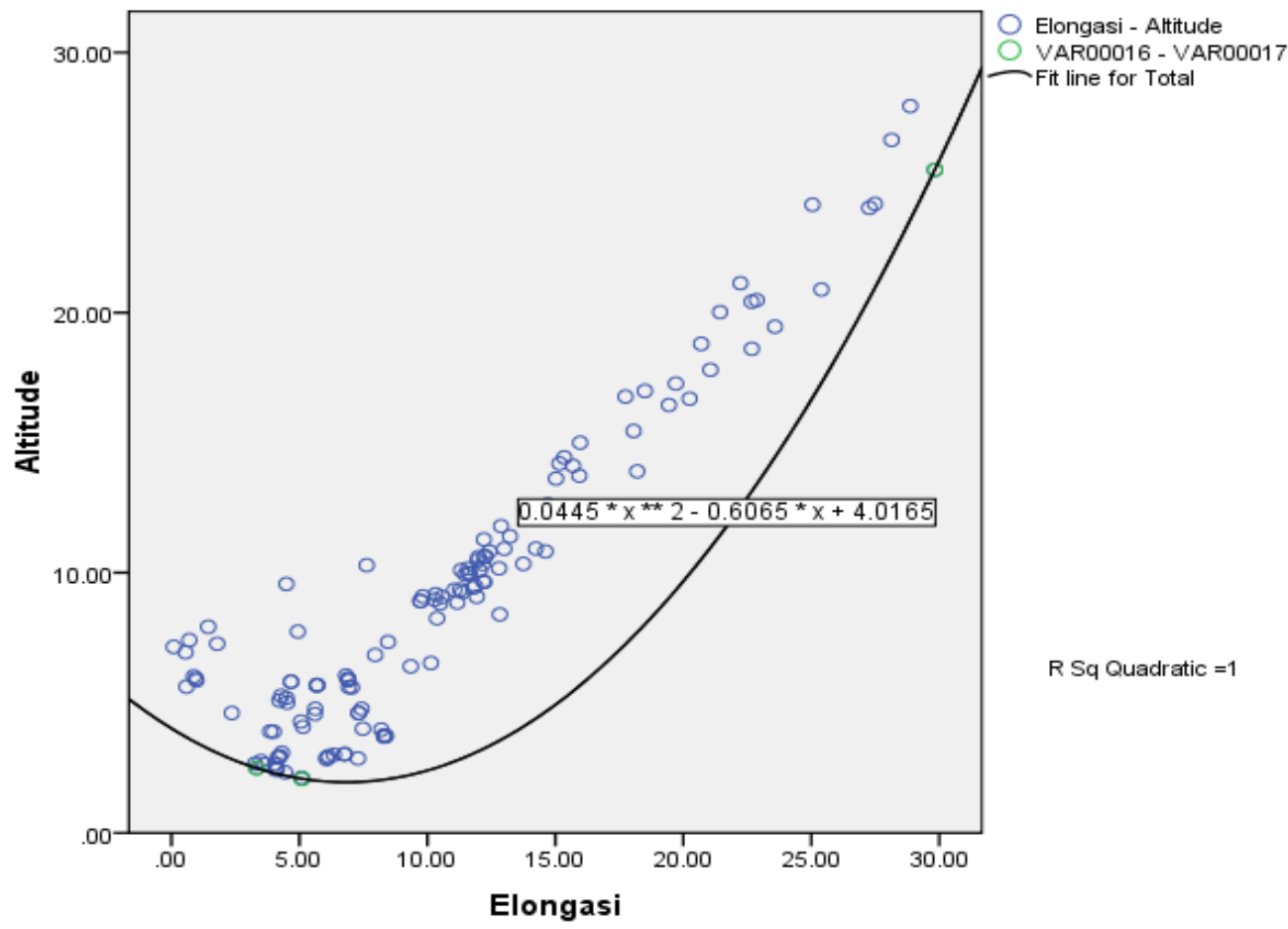

Gambar 6 Kriteria Visibilitas Hilal, Altitude - Elongasi

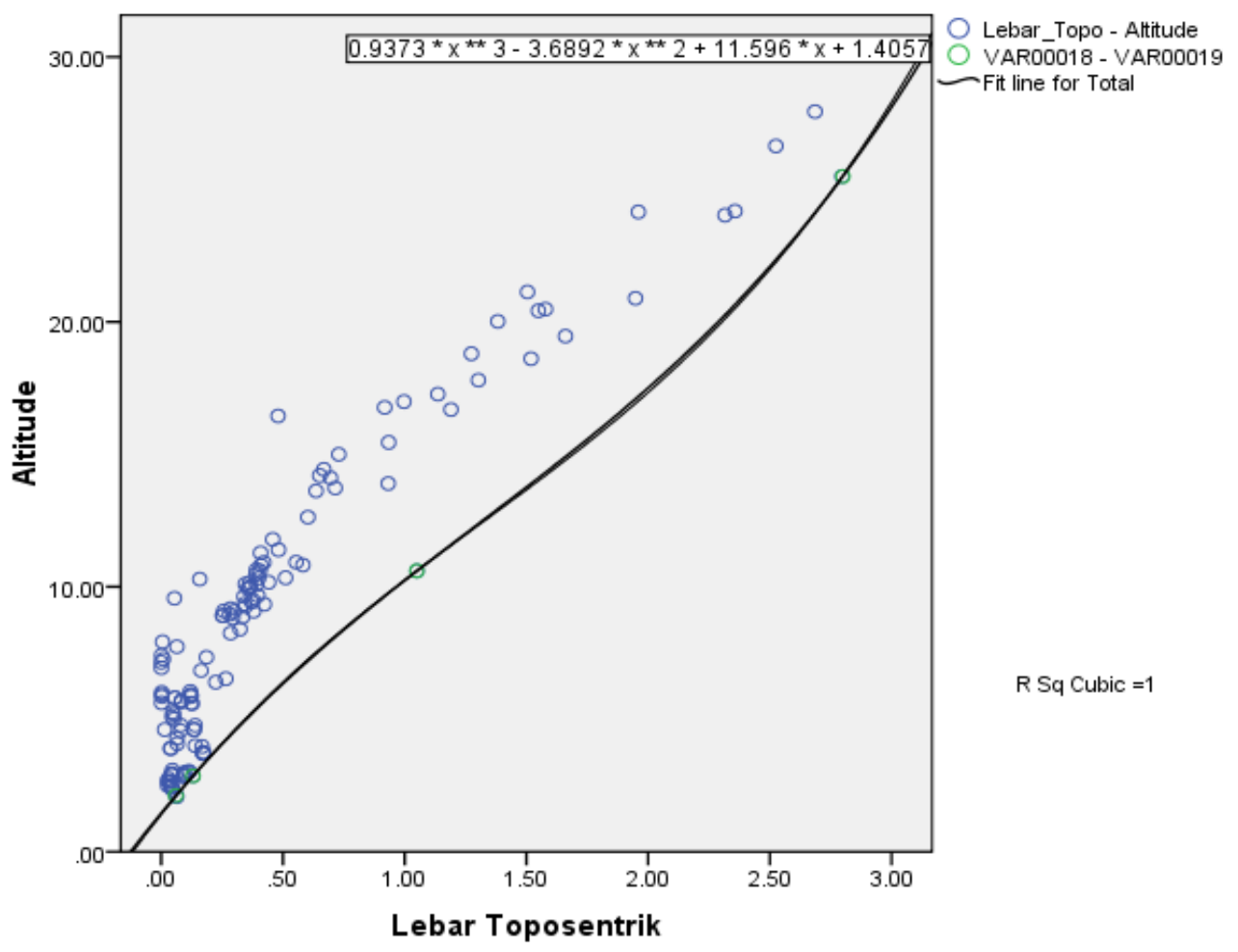

Gambar 7 Kriteria Visibilitas Hilal, Altitude - Lebar Hilal 
Dari kurva kriteria visibilitas hilal altitude-selisih azimut, dapat diperoleh informasi bahwa ketika selisih azimut bernilai nol, altitude bernilai $5,915^{\circ}$. Semakin diperbesar nilal selisih azimut, nilai altitude semakin rendah hingga mencapai titik balik minimumnya ketika selisih azimut bernilai $5,572^{\circ}$ dan altitude $2,145^{\circ}$. Setelah melewati titik balik minimum, pertambahan nilai selisih azimut diikuti pula oleh bertambahnya nilai altitude. Koefisien determinasi yang bernilai 0,9886 (mendekati 1) menandakan bahwa ada faktor-faktor lain yang memengaruhi kriteria visibilitas hilal tidak hanya kedua variabel ini.

Dari kurva kriteria visibilitas hilal altitude-elongasi, dapat diperoleh informasi bahwa ketika elongasi bernilai nol, altitude bernilai $4,016^{\circ}$. Nilai ini lebih rendah dibandingkan dengan nilai altitude ketika selisih azimut bernilai nol. Kemudian, semakin besar elongasi maka nilai altitude semakin rendah, kecenderungan ini hampir sama dengan yang dialami oleh selisih azimut ketika diperbesar. Elongasi diperbesar hingga mencapai titik balik minimumnya ketika bernilai $6,815^{\circ}$ dan altitude $1,950^{\circ}$. Koefisien determinasi tepat bernilai 1 menandakan bahwa outlier kedua variabel ini sangat signifikan.

\section{Kesimpulan}

Berdasarkan analisis data dan pembahasan sebelumnya dapat disimpulkan bahwa: Melihat dari signifikasi hubungan variabel visibilitas hilal, kriteria visibilitas hilal dibentuk dari parameter altitude toposentik, selisih azimut, elongasi dan lebar hila ketika Matahari terbenam. Ada tiga persamaan yang dibentuk dari variabel tersebut yakni: Kriteria Altitude-Selisih Azimut dengan persamaan $\boldsymbol{h} \geq \mathbf{0 , 1 2 1 4}$ $D A z^{2}-1,353|D A z|+5,9147^{\circ}$ memiliki titik balik minimum pada $5,572^{\circ}$ untuk selisih azimut dan $2,145^{\circ}$ untuk altitude. Kriteria Altitude-Elongasi dengan persamaan $h \geq 0,0445 A R C L^{2}-0,6065$ $A R C L+4,0165^{\circ}$ memiliki titik balik minimum pada $6,815^{\circ}$ untuk elongasi dan $1,950^{\circ}$ untuk altitude, dan kriteria Altitude-Lebar Hilal dengan persamaan $h \geq 0,9373 W^{, 3}-3,6892 W^{, 2}+$ $11,596 W^{\prime}+1,4057^{\circ}$ memiliki titik belok pada 1,312 menit busur untuk lebar hilal dan $12,386^{\circ}$ untuk altitude. Bulan dapat dikatakan sebagai hilal jika altitude terletak di antara $1,950^{\circ}$ hingga $12,386^{\circ}$ dengan elongasi minimum 
$6,815^{\circ}$ dan selisih azimut $5,572^{\circ}$. Ketika altitude lebih rendah dari $1,950^{\circ}$ pada waktu Matahari terbenam, bulan masih dapat dikatakan sebagai Bulan Baru meskipun umur hilal sudah positif. Sedangkan ketika altitude lebih tinggi dari $12,386^{\circ}$ pada waktu Matahari terbenam, maka Bulan tidak bisa disebut lagi sebagai hilal melainkan sabit mengembang (waxing crescent).

Bertolak dari kesimpulan dan temuan-temuan dalam penelitian ini, maka saran-saran yang dapat diberikan sebagai berikut:

Bagi ahli falak dan pengguna kriteria imkanurrukyat: Kriteria imkanurrukyat tidak hanya semata-mata dibentuk dari segi astronomis melainkan juga fikih. Antara fikih dengan astronomis merupakan satu kesatuan dan tidak dapat dipisahkan. Dikotomi antara aspek fikih dan aspek astronomis dalam kriteria imkanurrukyat lebih disebabkan karena kurangnya data-data pengamatan hilal di lapangan secara astronomis. Penerimaan kesaksian rukyatul hilal juga semata-semata didasarkan pada asepk legalitas formal (dalam hal ini fikih) namun mengabaikan aspek fisis objek yang diamati (yakni hilal, sebagai objek astronomis). Dengan melakukan pengamatan hilal yang berkualitas secara berkesinambungan, aspek fikih dan astronomis dapat terintegrasi sehingga diperoleh kriteria yang lebih valid dan dapat menghindari perbedaan pendapat mengenai keduanya.

Bagi peneliti selanjutnya Penggunaan peranti lunak (software) sangat membantu dalam melakukan pemodelan kriteria visibilitas hilal dengan lebih akurat dan presisi dan tidak hanya itu, dapat juga memprediksi di koordinat manakah hilal diduga dapat terlihat pertama kali di permukaan Bumi. Keterbatasan penulis dalam penelitian ini sekiranya dapat diatasi bagi para peneliti selanjutnya jika ingin membahas topik mengenai kriteria visibilitas hilal lebih jauh.

Bagi masyarakat Dinamika perkembangan kriteria imkanurrukyat atau visibilitas hilal ini merupakan buah dari bidang keilmuan sains khususnya astronomi yang selalu terbuka menerima hal-hal yang baru selama dapat dipertanggungjawabkan selama ilmiah dengan bukti-bukti empiris. Perkembangan ini hendaknya dapat disikapi secara arif dan tidak menganggap bahwa sains (dalam hal ini 
kriteria imkanurrukyat) adalah hal yang mutlak dan tetap. Meskipun demikian, perlunya suatu kriteria tunggal yang terintegrasi antara fikih dan astronomis adalah bentuk tanggungjawab sosial para ahli di bidangnya kepada masyarakat.

\section{Daftar Pustaka}

Hoffman, R.E. Observing the New Moon. Mon. Not. R. Astron. Soc. 2003, 340.

Ilyas, M. (1984). A Modern Guide to Astronomical Calculations of Islamic Calendar, Times and Qibla. Berita, Kuala Lumpur.

Odeh, M. Sh. (2004). New Criterion for Lunar Crescent Visibility. Experimental Astronomy.

Rekavitulasi Data Rukyatul Hilal, Badan Hisab dan Rukyat Kementerian Agama RI, 1962-2010.

Data hilal positif 2008-2015, Badan Meteorologi dan Geofisika (BMKG) RI. 